\title{
A NOTE ON THE IMPLICATIONS OF THE OIL PRICE INCREASES FOR BRITISH AID POLICY
}

\author{
H.W. Singer*
}

Introduction

The rise in oil prices and oil-based products being a watershed in relations with the Third World generally, it would be surprising if it did not also have profound implications for British development policy. This is indeed the case and the following note tries to identify a few of such implications. The short-run need is to recycle oil revenues to the Third World and to take measures to provide immediate relief to, or indeed prevent a collapse of, the hardest hit NOPEC countries - the poorer members of the Third World who are net oil importers and are not compensated by rises in their export prices. To meet these short-term measures, there looms a need for structural adjustments to create an international order in which the poorer NOPEC countries can find a place, safeguarding their development hopes and maintaining their economic dignity and independence.

The elements of such a new international order have emerged from the recent United Nations Special General Assembly Session devoted to a "Study of the problems of raw materials and development". These elements include: the creation of an autonomous technological capacity within the Third World and better transfer of rich-country technology; new international monetary relations under a strengthened IMF, including the long-delayed establishment of the "link" between SDRs and Third World development needs; the establishment of world food reserves and world food security at the coming November World Food Conference; maintenance and stabilisation of export prices of Third World countries, including commodity agreements and compensatory stabilisation schemes; better market access for agricultural, processed and manufactured goods, more and better aid and strengthened multilateral aid mechanisms; and a new and more constructive role for multinational

* H.W. Singer is a Fellow of the Institute. 
A NOTE ON THE IMPLICATIONS OF THE OIL PRICE INCREASES FOR BRITISH AID POLICY

corporations and private investment. The basic need for British development policy is to play a constructive role in creating this new international order. The note which follows does not discuss Britain's potential role in such an overall world policy in detail, but rather deals with some direct and limited measures, particularly emphasising those that can be taken within the framework of the EEC.

The implications of the price increases for aid availability and aid need

In one sense, the world development picture has become clearer. The homogeneity of the Third World has been shattered. Those resource-rich members of the Third World who benefit greatly from the increase in oil and other commodity prices - principally, of course, the oil producers - will no longer be in need of aid, except possibly some technical assistance (which normally they should be expected to pay for themselves, with the possible exceptions of Nigeria and Indonesia). Indeed, the oil producers may be expected to join the ranks of the aid donors and this will ease, in one sense at least, the situation of the traditional donors, politically as well as financially. This could also apply to the Second World, the centrally planned economies, which on the whole have benefited from oil developments. It should be emphasised that if the GNP criterion is continued as an indication of aid-giving capacity, the contribution to total aid flows of the oil producers would be relatively modest (perhaps 15 per cent or so of the total). On the other hand, if special aid funds are set up to deal specifically with the impact of rising oil prices, the contribution of oil producers to such special aid funds could be expected to be higher than their proportionate contribution to the overall flow - perhaps more in the nature of 33 to 50 per cent.

Although it is true that the group of potential aid donors has been increased, it is equally the case that total aid-giving capacity has not been increased, since the increased capacity of oil producers has been acquired at the expense of the traditional Western aid donors. On the other hand, although the group of countries really in need of aid has been narrowed down by the rising commodity prices to those members of the Third World which have suffered from the increase, the magnitude of the need of those countries has been sharply, and 
A NOTE ON THE IMPLICATIONS OF THE OIL PRICE INCREASES FOR BRITISH AID POLICY

indeed desperately, increased. It is therefore particularly important to ensure that the widening of the group of potential aid donors, and the narrowing down of those in special need, must be accompanied by a rise in the overall flow of aid, to correspond to the increased overall need. Such an increase in the overall flow is in any case indicated by the large discrepancy between actual flows and the 0.7 per cent target (now accepted in principle by the British government). The idea of matching additional or special funds contributed jointly, or at least in agreed proportions, by the oil producers and the traditional aid donors is therefore to be considered as the reaction to this situation. The weight of British policy should be thrown fully and strongly behind such efforts.

It is also relevant to point out that those countries which are now in need of additional and special aid as a result of rising oil and other commodity prices (including fertilisers) are strongly concentrated in the Indian subcontinent. The Indian subcontinent has not been generously treated in the arrangements attending British entry into the EEC. It is in any case a matter of British policy - as indicated both in the EEC summit communiqué and in the agenda for re-negotiation of the terms of British entry - to press for full and generous compensation to these populous and very poor developing countries for the loss of Commonwealth preferences, and to prevent them from being placed at a disadvantage from not being offered association with the EEC. The recent treaty between the EEC and India is not reassuring in this respect, involving as it does "voluntary" export restraint by India for a number of important products. This makes it all the more desirable to concentrate additional or special aid funds on these countries, and it would be natural for the UK to expect the EEC to play a special and active part in the provision of such funds. This would satisfy simultaneously two objectives of British development policy:

(a) it would tend to make EEC aid more "global" by extending it beyond the ranks of associated countries;

(b) it would take account of the "special relationship" between the EEC and the Mediterranean and Middle Eastern area, insofar as it would involve matching of funds, or at least collaboration, between oil producers and traditional aid donors. 
A NOTE ON THE IMPLICATIONS OF THE OIL PRICE INGREASES FOR BRITISH AID POLICY

With the additional balance-of-payments burden on European countries, including the UK, arising from the higher oil prices and other adverse changes in terms of trade, it becomes particularly important to ensure that balance-of-payment arguments should not stand in the way of increased aid to the NOPEC countries. The principle that oil-induced balance-of-payments deficits should not be covered unilaterally by special national action has already been pronounced and accepted, and is supported by all enlightened opinion. In addition, however, it is important to underline at this moment that such an additional aid programme would not in fact cause an additional balance-of-payments deficit to the donor countries as a whole since it would enable the NOPEC countries to maintain their imports from the donors and/or maintain debt payments which otherwise would become simply uncollectable. The contributions of oil producers when spent by NOPEC countries in a similar way could actually serve to mitigate the primary balance-of-payments deficit.

The implications for types of aid and distribution amongst Third World countries

Although the situation has so far been discussed in terms of the quantity of aid, the moment has also come to seek another opportunity of concentrating more directly on the types of aid and on the countries where it is most needed and most effective. One way of doing this would be by giving "aid" to a number of countries in the form of opportunities for trade expansion rather than in more traditional forms of what is normally thought of as aid. This calls for a considerable strengthening of the GSP - the general system of preferences - in a number of directions:

(a) by extending its scope to include agricultural and processed commodities;

(b) by abolishing some of the limitations which prevent developing countries from taking real advantage of the scheme, such as maximum quotas;

(c) by making the scheme more reliable for developing country trade partners through removing or weakening the "sensitive list" and escape clause provisions; 
A NOTE ON THE IMPLICA'TIONS OF THE OIL PRICE INCREASES FOR BRITISH AID POLICY

(d) by producing a joint scheme for the US, EEC and Japan;

(e) by increasing the duration of the preferential commitment to a minimum of 10 and preferably 15 or 20 years; and

(f) by offering LDCs direct help and technical support in building up export industries and obtaining access and marketing outlets in the rich countries.

With such a scheme, financial aid can then be concentrated on the following three categories:- ${ }^{1}$

(a) aid to the least developed and poorest countries;

(b) aid to countries that are not yet in a position to engage in world trade, or take advantage of a strengthened GSP, until such time as they have developed the capacity to participate;

(c) countries hit by the rise in oil and other commodity prices, and not thems elves benefiting from such rises in prices.

Adjustment assistance and technology

It must be recognised, of course, that in the new context, trade "liberalisation" must be in the nature of balanced trade expansion rather than unilateral concessions. ${ }^{2}$ This is because of the balance-ofpayments difficulties of rich countries themselves. But since the governments of developing countries - other than some of the oil producers and perhaps one or two other countries - will in any case want to use all their available foreign exchange earnings for imports (hopefully development imports), this will to a large extent happen automatically; although there will be no harm in making sure of this through two-way long-term trade expansion agreements. It must be recognised that such a trade policy will create problems of partial adjustment within the UK and other industrialised countries. These problems of adjustment would have to be dealt with by active national adjustment policies as well as general policies of full

1 Many countries will fall into more than one of these categories.

2 See the paper by Michael Lipton in this bulletin. 
A NOTE ON THE IMPLICATIONS OF THE OIL, PRICE INCREASES FOR BRITISH AID POLICY

employment, and also in the case of EEC countries through the establishment of regional and social funds and policies. It should also be pointed out that the need for adjustment assistance should also be recognised in relation to developing country trade partners whose plans and employment are being disrupted through such trade restrictions of rich countries as are still introduced in spite of a strengthened GSP.

Nothing so far has been said of matters relating to technology, transfer of technology to developing countries and support for their own scientific and technological development. There is little doubt that industrialised countries would be able to neutralise the impact of higher oil prices and other commodity prices through appropriate technological adjustments, provided they have the concerted will to organise their tremendous technological power to this effect. NOPEC countries suffering from these rising prices do not have the same possibilities of adjustment or escape. Some of the technological adjustments likely to be made in the industrialised countries will be of a type inappropriate to the NOPEC countries, and in fact may well impose additional costs on them.

It would be desirable if the industrialised countries were to use some of their technological power to support NOPEC developing countries in making technological adjustments of a type appropriate to their needs and resources endowment. Of particular importance would be that some of the technological adjustment should take the form of replacing synthetic substitutes, especially those which are oil-based, by natural materials produced in developing countries. Research on the improvement and development of natural commodities has been notoriously neglected compared with technical research on synthetic substitutes, as a result of the tremendous concentration of technological capacity in the industrialised countries. A good example would be research and development work on pyrethrum so that it can be given the same degree of stability as DDT. Pyrethrum is produced in a number of poor countries - Ethiopia, Kenya, and Tanzania for example - and is a labour-intensive crop produced by smallholders. This development would satisfy the highest priority criteria for a better international division of labour, quite apart from environmental advantages. Other examples, including rubber, should 
A NOTE ON THE IMPLICATIONS OF THE OIL PRICE INCREASES FOR BRITISH AID POLICY

certainly also be included. Direct priority clashes in technological development can be foreseen. It is possible to order our technological priorities and actions to the mutual advantage of the developing countries as well as of ourselves.

\section{END NOTE}

The Select Committee on Overseas Development published its second report* at the end of July "The Oil Crisis and Third World Development: Implications for United Kingdom Policy" after taking evidence from ODM, HMT, the Department of Trade and the IDS. The Report's recommendations fall into three main categories:

(1) those relating to aid - that it should be increased; that it should be increasingly reallocated from those gaining to those losing from the oil crisis; that international comparisons of aid effort should exclude aid to richer (more than $\$ 500$ per head) countries; that debt relief and untying should be pursued; that the SDR link should be supported;

(2) those relating to policies other than aid which might help the poorest countries - that adjustment assistance be more effectively pursued; that EEC and GATT be pressed to liberalise trade; that multinationals be monitored and new ways of transmitting technology (for example from smaller firms) be pursued; that the Export Credit Guarantee Scheme be used to increase trade with the poorest countries;

(3) those relating to international financial flows - that better monitoring of international financial flows be pursued; that private financial flows to the (better off) Third World countries be encouraged (thus releasing funds for concessional finance to the worse off); support be given to all the multilateral international initiatives to channel surplus oil funds to the Third World.

\footnotetext{
* Because of the Stationery Office printers' strike the report was published in July in mimeo form; it should be available in printed form by the time this Bulletin appears.
} 